\title{
Biosafety of Stevia Extract Employing a Variety of Short-Term Genotoxic Bioassays
}

\author{
M. A. Ghonema \\ Genetic and Breeding Department, Sugar Crops Research Institute, Agriculture Research Center, Egypt.
}

\begin{abstract}
Current work was carried out to assess the possible genotoxic effect of the natural sweetener Stevia in causing DNA damage, in order to achieve such a purpose, the genetic material of mice (Mus musculus, $2 n=40$ ) and human (Homo sapiens, $2 n=46$ ) were chosen and used employing the following short-term genotoxic bioassays recommended by Environmental Protection Agency (EPA-USA): 1- Analysis of chromosomal abnormalities in mice bone-marrow cells; 2-Analysis of mice primary spermatocytes 3-Analysis of micronucleated polychromatic erythrocytes in mice; and 4- Chromosomal aberrations in human lymphocyte culture. The obtained results clearly showed that Stevia extractwas proven to be negative in causing DNA damage, which gave a strong evidence, at the level of the present study, that Stevia extract is recommended to be suitable for human usage.
\end{abstract}

Keywords: Stevia Extract, Biosafety, Short-Term, Genotoxic Bioassays.

\section{INTRODUCTION}

Stevia rebaudiana (Bertoni) is a small perennial shrub that has been used for centuries as a bio sweetener and for other medicinal uses such as to Lower Blood Sugar, Weight Loss, Microorganism inhibitor, oral tonic digestive aid and skin care. Its white crystalline compound (stevioside) is the natural herbal sweetener with no calories and is over 70-400 times sweeter than that of white sugar (Bharat et al., 2013).

In 1970, the Japanese food manufacturers began to use Stevia extracts as a natural sweetener. Now, about $40 \%$ of the sweetener Japanese market is Stevia based. Also, the use of products and extracts of Stevia are widespread throughout a lot of countries, such as China; Taiwan; Thailand; South Korea; Brazil; Malaysia; Indonesia; Argentina; Paraguay; Philippines; and Vietnam (Soejarto et. al., 1982).

In 1994, Egypt has registered Stevia as a natural sweetener for use in food. The products in which Stevia has been used include soft drink; ice cream; cookies; chewing gum; tea and skin care products. In addition, Stevia and its extract are very important in weight-loss programs for their ability to reduce craving sweet and fatty foods. This plant has also been used to treat some diseases such as diabetes; high blood pressure; skin abrasions and inhibiting growth and reproduction of bacteria-like plaque (Tomita et al., 1997). The gap between sugar production and consumption in Egypt is widening. In October 2013 Egypt had produced about 2012 Thousand Metric Tonnes (TMT) of sugar and imported 1208 TMT (GAIN Report, 2013/2014).

At the same time, five grams of stevioside can substitute one kilogram of table sugar. Thus, the cultivation of Stevia in Egypt as a main natural sweetener may reduce the gap between sugar production and consumption. Moreover, water requirements for the growth of sugarcane plants are relatively quite high, Sugarcane plant needs three times the water amount compared with Stevia, which requires approximately $300 \mathrm{~m}^{3}$ water/feddan. Also, Stevia can grow under different climatic conditions and in different type of soils (Jia, 1984). So, there is a great interest on the strategical agriculture plan for Stevia cultivation in the new land reclamation projects to meet the demands of the Egyptian 
markets and generate income for the growers.

Furthermore, stevia extracts can increase the palatability and attractiveness (enjoyment) of food through enhancement of flavors and odors (Ikan et al., 1993). Moreover, Stevia combines with other sweeteners to enhance their nutritive values (Shibata et al., 1991).

Genotoxins are agents that specifically producing genetic alterations at sub-toxic exposure levels which result in organisms with altered hereditary characteristics. Depending upon the developmental stage of an individual, a genotoxin can exert teratogenic effect or cause mutations not only in somatic cells but also in germinal ones (Brusick, 2003).

In the last few years, several investigators reported that no acute toxicity for stevioside was achieved in doses as large as $15 \mathrm{~g} / \mathrm{body}$ weight/day (Medon et al., 1982; Krejci and Koechel, 1992 and Toskulkao et al., 1997). It seems that no acute toxicity for stevioside but several question of concern were raised regarding the specifications of the stevia extract that had been tested, questionable chronic toxicity and carcinogenicity studies and possible effects on the male reproductive system that could affect fertility.

There are many systems to test mutagenicity using Drosophila as a genetic model to detect different genetic end points such as dominant lethal mutations (Würgler et al., 1986); Bacteria (Terai et al., 2002) and Saccharomyces cerevisiae (Badawy et al., 2004).

The present investigation was carried out to study the biosafety of stevia extract employing a variety of short-term genotoxic bioassays. To achieve such a purpose the genetic materials of mice (somatic \& germinal) and of human genomes were used.

\section{MATERIALS AND METHODS}

The present study aims to assess the possible genotoxity of Stevia extract (biosafty) employing mice (Mus musculus, $2 \mathrm{n}=40$ ) and Human (Homo sapiens, $2 n=46)$ genomes.

Stevia rebaudiana (Bertoni); Stevia 1108 and Stevia 9B-11 were imported from USA through the Faculty of Agriculture, Alexandria University, Egypt. An additional stevia variety namely Sponti was obtained from Sugar Crops Research Institute (SCRI), Agricultural Research Center (ARC), Ministry of Agriculture, Egypt.

Stevia rebaudiana (Bertoni) seeds were cultivated in pots (Bitmos : sand : clay) (1:1:1) at green house at Sabahia Agricultural Research Station in December 2013. The plants were harvested in mature stage before flowering.

Albino Swiss mice, Webster strain, weighting of $20 \pm 2 \mathrm{~g}$ were purchased from Faculty of Medicine, Alexandria University, Alexandria, Egypt. Animals were housed in cages in a room kept at $21^{\circ} \mathrm{C}$ with a $12 \mathrm{~h}$ light/dark cycle, and given food and water ad libitum the local committee approved the design of the experiments, and the protocol conforms to the guidelines of the National Institutes of Health (NIH).

Heparinized human blood samples were taken from healthy volunteers 20-22 years old. They were non-smokers, non-subjected to any medical treatment. 


\section{Preparation of aqueous extract of Stevia leaves}

Extraction of Stevia sweeteners has been carried out with water for each genome (Mondal et al., 2012). Fresh leaves of Stevia washed thoroughly tap water then were dried in an electric oven (E. Schulz \& Co. Inh. Franz. Skorezewsh KG). The dry leaves were ground into coarse powder by a hammer mill, then sieved through 60 mesh sieve, and finally stored in polyethylene bags until used. About $10 \mathrm{~g}$ of the ground leaves were extracted with 1.0 liter of hot water $\left(80^{\circ} \mathrm{C} \pm 5^{\circ} \mathrm{C}\right)$ in a thermostatically controlled water bath for $2 \mathrm{hrs}$ and then filtered through filter paper (Whatman No.4). The filtrate was freeze-dried using lyophilizer into powder and stored at $4^{\circ} \mathrm{C}$. Stevia sweetener extract was determined through HPLC (high-performance liquid chromatography) as given by Kolb et al. (2001) Figure (1).

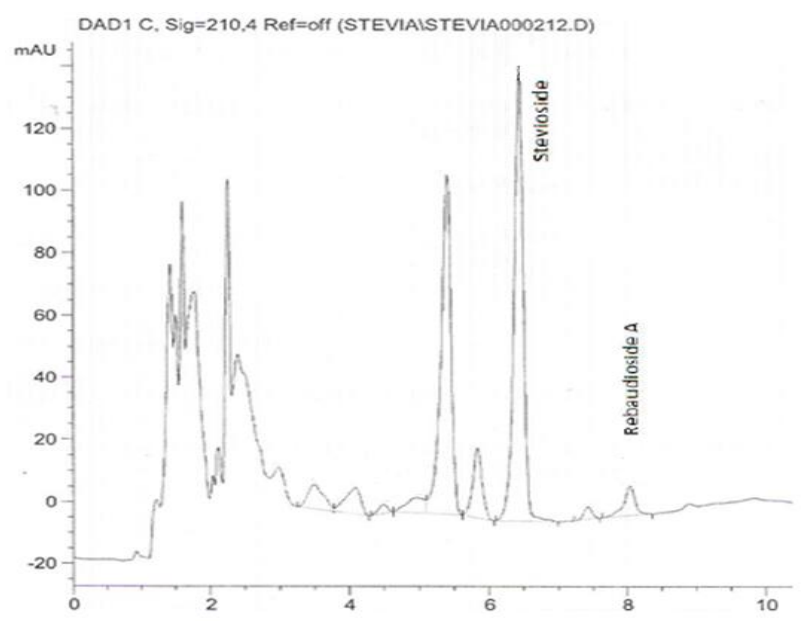

Figure (1): Chromatogram of Stevia sweetener from Sponti extract

(HPLC system Linear gradient 84 to $55 \% \mathrm{CH}_{3} \mathrm{CN} / \mathrm{H}_{2} \mathrm{O}, \mathrm{H}_{3} \mathrm{PO}_{4}, \mathrm{pH}=5$ ), over 20 min, detection at $\lambda=$ $210 \mathrm{~nm}$, Agilent 1200 PDA detector, Eclipse plus $\mathrm{C}_{18}$ column $(3.5 \mu \mathrm{m} 4.6 \times 250 \mathrm{~mm})$; flow rate 2.0 $\mathrm{mL} / \mathrm{min}$.)

\section{Experimental design}

Treatments were divided into three groups as follow: Group I (as negative control), the animals received distilled water, Group II (as a positive control), each animal was given $1 \mathrm{ml}$ of indoxan (cyclophosphamide) two times daily for 10 days (25 mg/kg b. wt.), while Ethyl methane sulfonate (EMS) with a concentration of $0.02 \mathrm{M}$ was used as a positive control in human lymphocyte, and the animals in groups III were obtained one $\mathrm{ml}$ of Stevia extract two times daily which contains $500 \mathrm{mg}$ of Stevia sweeteners, for a month, while in the primary spermatocytes treatment, the dose was orally given three times daily which contains $750 \mathrm{mg}$ of Stevia sweeteners, for a week. Four mice were used for Stevia extract treatment including the negative and positive control as well.

The following genotoxic bioassays were chosen and used:

1- Analysis of chromosomal abnormalities in mice bone-marrow cells,

2- Analysis of mice primary spermatocytes,

3- Analysis of micronucleated polychromatic erythrocytes in mice, and 
4- Chromosomal aberration in human lymphocyte cultures.

\section{Analysis of chromosome behavior in mice bone marrow cells}

The treated animals were killed by decapitation $24 \mathrm{hrs}$ after the last dose. Three hours prior to killing, the animals were injected with $0.6 \mathrm{mg} / \mathrm{kg}$ of colchicine. After killing, the adhering soft tissues and epiphyses of both tibiae were removed. The marrow was aspirated from the bone, transferred to phosphate buffer saline, centrifuged at $1200 \mathrm{rpm}$ for 5 minutes and the pellet resuspended in $0.075 \mathrm{M} \mathrm{KCl}$. Centrifugation was repeated and the pellet was resuspended in fixative solution (methanol: acetic acid, 3:1). The fixative was changed after 2 hours and the cell suspension was left overnight (in a refrigerator).

\section{Slide preparation and staining}

Cells in fixative were dropped on a very clean glass slide and air-dried. Spreads were stained with $10 \%$ Giemsa at PH 6.8 for 5 min.

\section{Screening of slides}

Slides were coded and scored for chromosomal aberrations e.g., gaps, deletion, fragment, break, stickiness and hyperploidy. A mitotic index based on at least 1000 counted cells was recorded. For chromosomal abnormalities, at least 200 metaphase cells per dose were recorded. The comparison between treatments and control groups were statistically done.

\section{Analysis of mice primary spermatocytes}

Four male mice were used for each treatment. The dose was orally given three times daily which contains $750 \mathrm{mg}$ of Stevia sweeteners, for a week. Ten days after the last dose, animals were killed by cervical dislocation. The used procedure follows basically the description given by Oud et al. (1979); Adler (1984); Seehy and Osman (1989) and Seehy (2007).

Tissue sampling: The testes were removed by making an incision into the scrotum and fat tissue was cleaned. The tunica were removed, transferred the tubules to a small Petri dish containing a piece of fly mesh and 3-4 $\mathrm{ml}$ of 2.2 $\%$ tri-sodium citrate. The tubules were cut up with forceps several times, and then they were mashed on the fly mesh with flat-top forceps. The fluid containing the cells was transferred to $12 \times 100 \mathrm{~mm}$ round-bottom centrifuge tubes, centrifuged at $1000 \mathrm{rpm}$ for $5 \mathrm{~min}$. supernatant was completely discarded. The hypotonic solution ( $1 \%$ trisodoum citrate) was slowly added and centrifuged, after 15-20 min, and then the cells were fixed in (methanol: glacial acetic acid, 3:1). The fixative was changed twice after $10 \mathrm{~min}$ for each by centrifugation between changes.

\section{Staining}

The slides were stained for at least 10 min using $10 \%$ Giemsa $(\mathrm{PH}=$ 6.8), washed and air-dried.

\section{Micronucleus test in mice}

Male and female of strain Swiss albino, from randomly bred colony were used in the micronucleus assay. Four animals were used for each treatment. Each animal was received the proper dose of Stevia extract. The animals of the negative and positive control groups were received the proper volume of deionized water and cyclophosphamide, respectively. 


\section{Extraction of bone-marrow}

Animals were killed after $24 \mathrm{hrs}$ of the treatment time. The adhering soft tissue and epiphyses of both tibiae were removed. The marrow was aspirated from the bone, transferred to centrifuge tubes containing $5 \mathrm{ml}$ fetal calf serum (one tube for each animal).

\section{Preparation of the smears}

Bone-marrow smear was made according to Schmid (1975). The tubes were centrifuged at $1200 \mathrm{rpm}$ for $5 \mathrm{~min}$., the supernatant was removed and a small drop of the viscous pellet was transferred on the end of a slide and spread by a cover glass held at an angle of about 45 degrees. The preparation was then air-dried.

\section{Staining}

The preparations were stained in ordinary vertical staining jar according to method described by Gollapudi and Kamara (1979). The slides were fixed in absolute methanol for 5 min., rinsed twice in deionized distilled water, stained for $10 \mathrm{~min}$. in Giemsa (1:6 Gurr's R-66 Giemsa in deionized water), rinsed again thoroughly in deionized distilled water, air-dried, cleaned in xylene for 3 min and mounted.

\section{Screening of slides}

A thousand polychromatic erythrocytes per animal (4000 per treatment) were scored using a special hand counter. The frequency of micronucleated cells was expressed as percent of micronucleated cells based on the total polychromatic erythrocytes percent.

In this part of study, only polychromatic erythrocytes were scored according to Brusick (1986). Micronuclei were identified as dark-blue staining bodies in the cytoplasm of polychromatic erythrocytes. The data obtained from this study were analyzed according to Hart and Pederson (1983).

\section{Analysis of chromosomal abnormalities in human lymphocytes}

In order to investigate the possible activity of the extract in causing chromosomal abnormalities in human chromosomes, the same procedure as that described by Seehy and Osman (1989) was used. Ethyl methane sulfonate (EMS) with a concentration of $0.02 \mathrm{M}$ was used as a positive control. At $70 \mathrm{hrs}$. of incubation at $37^{\circ} \mathrm{C}$ colcemid was added to each tube. At 72 hrs. after initiation of the cultures, harvest the cells and prepared slides and stained by Giemsa 10\%.Chromosomes were investigated for deletion, gaps, and fragment. ...etc.

\section{RESULTS}

As mentioned before, this work was carried out to detect the possible genotoxic effect (Macro DNA damage) of Stevia rebaudiana (Bertoni) employing Mice (Mus musculus, $2 \mathrm{n}=40$ ) and Human (Homo sapiens, $2 \mathrm{n}=46$ ).

The data obtained from the analysis of mice bone marrow after treatment with the variety Sponti and two American Genotypes Stevia 1108 and Stevia 9B-11 in addition to the negative as well as positive control were summarized in Table (1).

As shown in Figure (2) total percentages of aberrant metaphases were $21.5 \%$ and $81 \%$ for the negative and positive control, respectively. However, 
they were $30.5 \%, 18.5 \%$, and 15\% for the genotypes Sponti, 1108 and 9B-11.

Table (1): Percentage of chromosomal abnormalities in mice bone marrow cells after treatment with tested Stevia extract (Sponti, 1108 and 9B-11), negative control and positive control

\begin{tabular}{|c|c|c|c|c|c|c|c|}
\hline \multirow[b]{2}{*}{$\begin{array}{l}\text { Genotype } \\
\text { and } \\
\text { treatment }\end{array}$} & \multicolumn{5}{|c|}{ Type of aberrations } & \multirow[b]{2}{*}{$\begin{array}{c}\text { Total } \\
\text { aberrant }\end{array}$} & \multirow[b]{2}{*}{$\begin{array}{c}\text { Percentage of } \\
\text { total aberrant } \\
\text { metaphases }\end{array}$} \\
\hline & 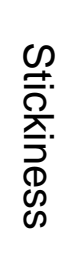 & $\begin{array}{l}\frac{\nabla}{\mathbb{D}} \\
\frac{\mathbb{D}}{\bar{D}} \\
\frac{0}{x}\end{array}$ & 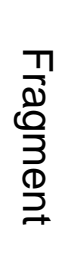 & กֶ & 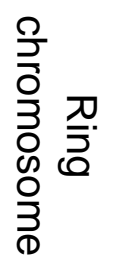 & & \\
\hline Sponti & 13 & 12 & 10 & 3 & 20 & 61 & 30.5 \\
\hline 1108 & 12 & 4 & 10 & 3 & 8 & 37 & 18.5 \\
\hline $9 B-11$ & 11 & 8 & 3 & 2 & 6 & 30 & 15 \\
\hline $\mathrm{NC}$ & 9 & - & 30 & 1 & 3 & 43 & 21.5 \\
\hline PC & 44 & 40 & 48 & 9 & 21 & 162 & 81 \\
\hline
\end{tabular}

NC: Negative Control.

PC: Positive Control.

200 cells were counted.

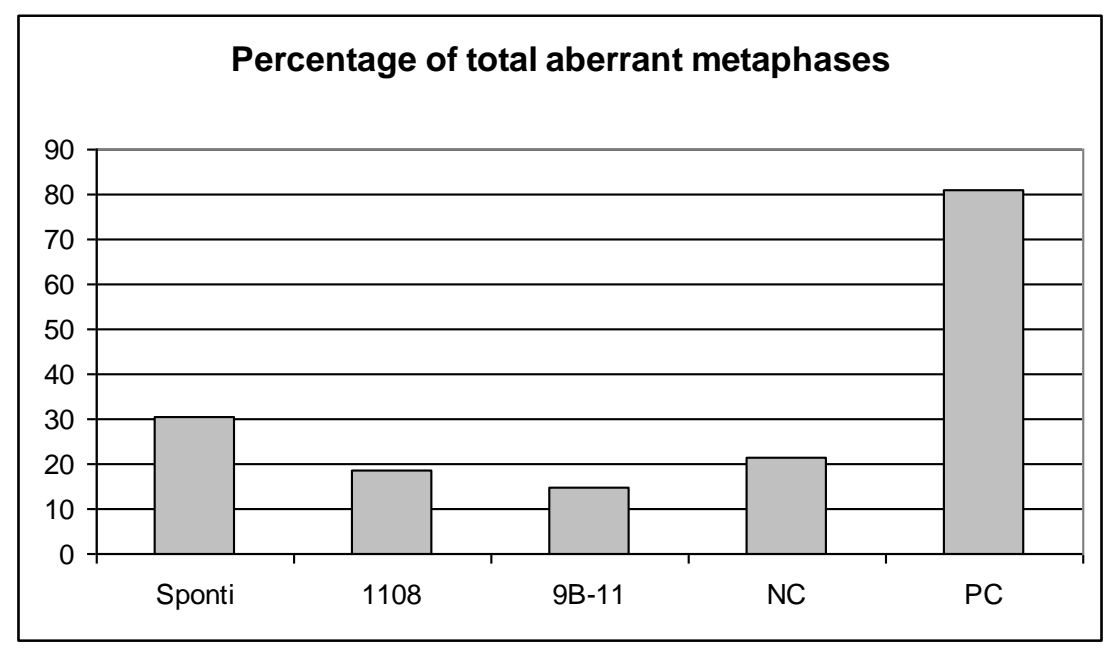

Figure (2): Percentage of total aberrant metaphases in mice bonemarrow cells after treatment with Stevia extract (Sponti, 1108 and 9B-11), negative and positive control.

Statistical analysis in Table (2) shows that all tested varieties of Stevia were found to be not significant. 
Table (2): Statistical analysis (Chi square $x^{2}$ ) of chromosomal abnormalities in mice bone marrow cells after treatment with tested Stevia extract (Sponti, 1108 and 9B-11), negative control and positive control

\begin{tabular}{ccccc}
\hline Genotypes & Obs. & Exp. & $\begin{array}{c}\text { (Obs.- } \\
\text { Exp. })^{2} \\
\text { /Exp. }\end{array}$ & $\begin{array}{c}\text { Chi square } \\
\text { tabulated }\end{array}$ \\
\hline Sponti & 61 & 52 & 1.6 & \\
1108 & 37 & 40 & 0.225 & $\mathrm{df}=1$ \\
9B-11 & 30 & 36.5 & 1.16 & at $0.05=3.841$ \\
NC & 43 & 0 & 0 & \\
PC & 162 & 102.5 & 34.5 & \\
\hline
\end{tabular}

Table (3) and Figure (3) show comparison between Sponti variety and the American ones in addition to the negative as well as positive control. All varieties were proven to be negative in causing significant aberration in mice primary spermatocytes. Total percentages of aberrant diakinesis were $14.5 \%$ and $77 \%$ for the negative and positive control respectively. However, they were $5.5 \%, 13 \%$, and $9.5 \%$ for the varieties Sponti, 1108 and 9B-11.

Table (3): Percentage of abnormalities in mice primary spermatocytes after treatment with Stevia extract (Sponti, 1108 and 9B-11), negative and positive control

\begin{tabular}{|c|c|c|c|c|c|c|c|c|c|}
\hline \multirow[b]{2}{*}{$\begin{array}{l}\text { Genotype } \\
\text { and } \\
\text { treatment }\end{array}$} & \multicolumn{7}{|c|}{ Type of aberrations } & \multirow[b]{2}{*}{$\begin{array}{c}\text { Total } \\
\text { aberrant } \\
\text { diakinesis }\end{array}$} & \multirow[b]{2}{*}{$\begin{array}{c}\text { Percentage } \\
\text { of total } \\
\text { aberrant } \\
\text { diakinesis }\end{array}$} \\
\hline & $\begin{array}{l}\frac{0}{\frac{0}{x}} \\
\frac{\partial}{0} \\
\frac{0}{2}\end{array}$ & $\begin{array}{l}\text { 卫 } \\
\Omega \\
\text { 乃 }\end{array}$ & 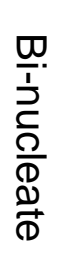 & 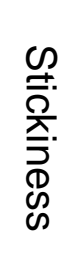 & 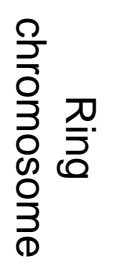 & 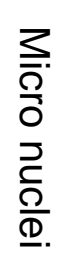 & 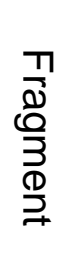 & & \\
\hline Sponti & 1 & - & 3 & 4 & 2 & 1 & - & 11 & 5.5 \\
\hline 1108 & - & 2 & 4 & 10 & 3 & 1 & 6 & 26 & 13 \\
\hline 9B-11 & - & 1 & 8 & 4 & 3 & 1 & 2 & 19 & 9.5 \\
\hline $\mathrm{NC}$ & - & - & 8 & 16 & 2 & 2 & 1 & 29 & 14.5 \\
\hline $\mathrm{PC}$ & - & 11 & 7 & 66 & 26 & 2 & 42 & 154 & 77 \\
\hline
\end{tabular}

NC: Negative Control.

PC: Positive Control.

200 cells were counted.

RCF: Robertsonian Centric Fusion 


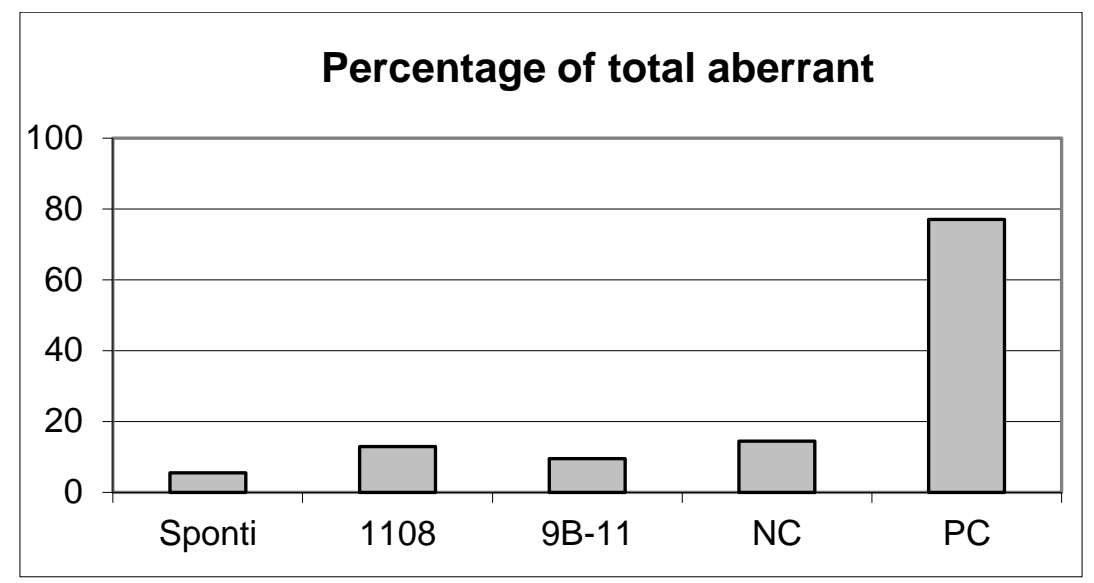

Figure (3): Percentage of abnormalities in mice primary spermatocyte cells after treatment with tested Stevia extract (Sponti, 1108 and 9B-11), negative control and positive control.

Table (4) revealed that, there was a significant increase in aberrations after treatment with positive control while negative control and all tested genotypes of Stevia were found to be not significant.

Table (4): Statistical analysis (Chi square $\mathrm{x}^{2}$ ) of abnormalities in mice primary spermatocyte after treatment with tested Stevia extract (Sponti, 1108 and 9B-11), negative control and positive control

\begin{tabular}{ccccc}
\hline Treatments & Obs. & Exp. & $\begin{array}{c}\text { (Obs.-Exp.) } \\
\text { /Exp. }\end{array}$ & $\begin{array}{c}\text { Chi square } \\
\text { tabulated }\end{array}$ \\
\hline Sponti & 11 & 20 & 4.05 & df $=1$ \\
1108 & 26 & 27.5 & 0.08 & at $\mathbf{0 . 0 5}=\mathbf{3 . 8 4 1}$ \\
9B-11 & 19 & 24 & 1.04 & \\
NC & 29 & 0 & 0 & \\
PC & 154 & 91.5 & 42.7 & \\
\hline
\end{tabular}

Table (5) and Figure (4) show the effect of Stevia extract upon the induction of micronucleated polychromatic erythrocyte (MNPE). Positive control gave $1.75 \%$, while negative control gave $0.25 \%$. This percentage ranged from 0.5 to $1.25 \%$ for genotypes Sponti and 9B-11, respectively.

Table (5): Micronucleated polychromatic erythrocyte (MNPE) in mice bone-marrow cells after treatment with tested Stevia Extract

\begin{tabular}{ccc}
\hline $\begin{array}{c}\text { Treatment and } \\
\text { genotypes }\end{array}$ & No. of MNPE & MNPE\% \\
\hline Sponti & 20 & 0.50 \\
$\mathbf{1 1 0 8}$ & 40 & 1.00 \\
9B-11 & 50 & 1.25 \\
N.C & 10 & 0.25 \\
P. C & 70 & 1.75 \\
\hline
\end{tabular}


Number of examined cells $=4000$ cells

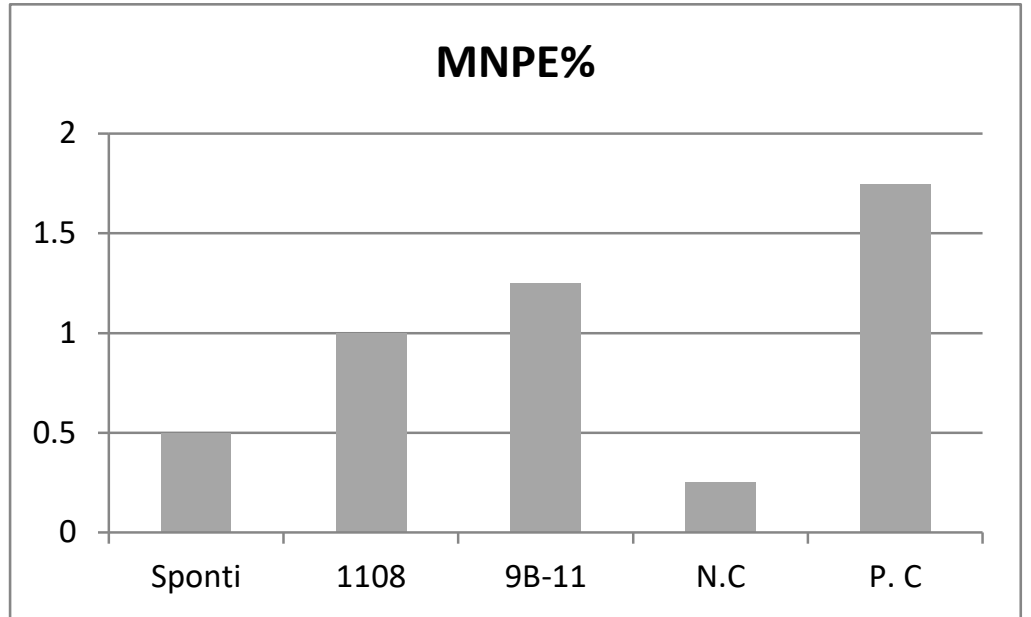

Figure (4): Micronucleated polychromatic erythrocyte (MNPE) in mice bone-marrow cells after treatment with Stevia Extract.

Figures $5-24$ illustrate the effect of Stevia extract upon mice genome compared with the positive control. Figures $25-29$ show the effect upon human chromosomes.

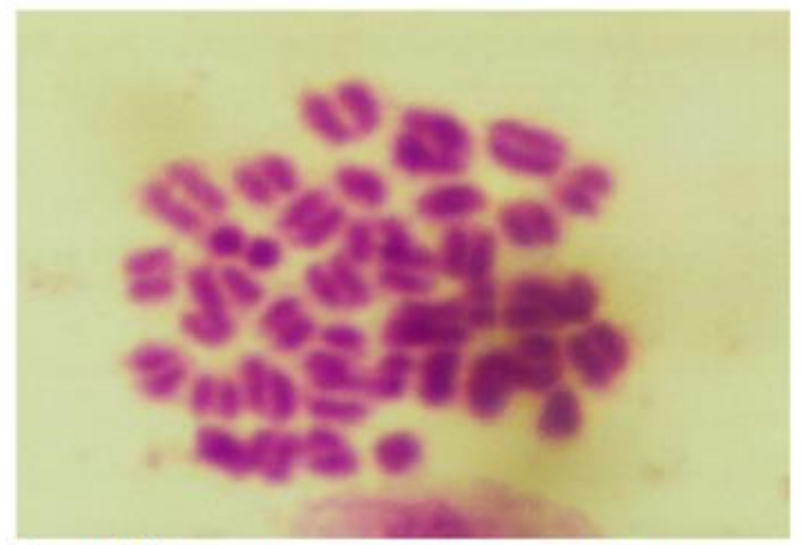

Figure (5): Photomicrograph showing speamatogonial cell with polyploidy of mice treated with Sponti variety extract.

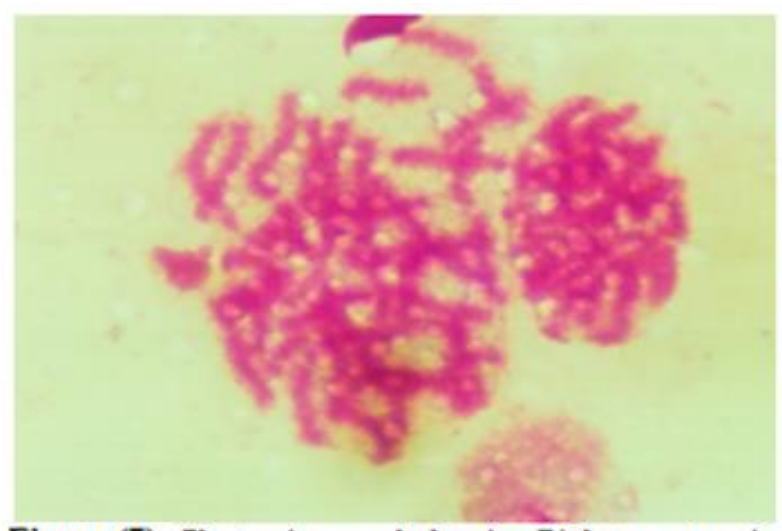

Figure (7): Photomicrograph showing Diplotene stage in mice primary spermatocytes after treatment with variety (1108) extract.

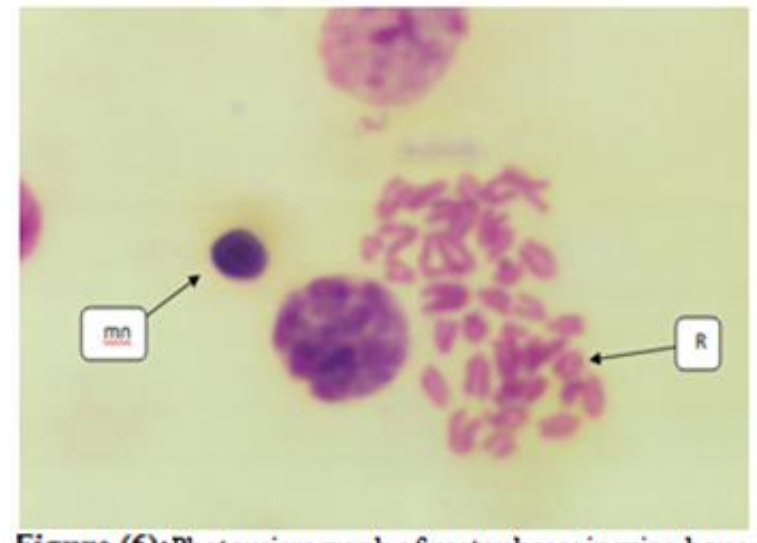

Figure (6): Photomicrograph of metaphases in mice bone marrow showing Ring chromosome (R) and Micronucleus $(\mathrm{mn})$ a fter treatment with varietv (1108) extract.

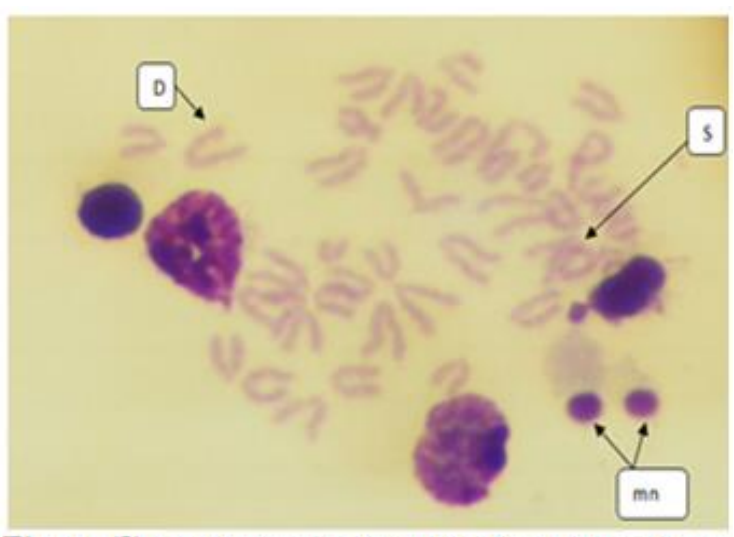

Figure (8): Photomicrograph of metaphases in mice bone marrow chromatide deletion(D) and Stickiness (S) and Micronucleus ( $\mathrm{mn}$ ) a fter treatment with variety $(9 B-11)$ extract. 


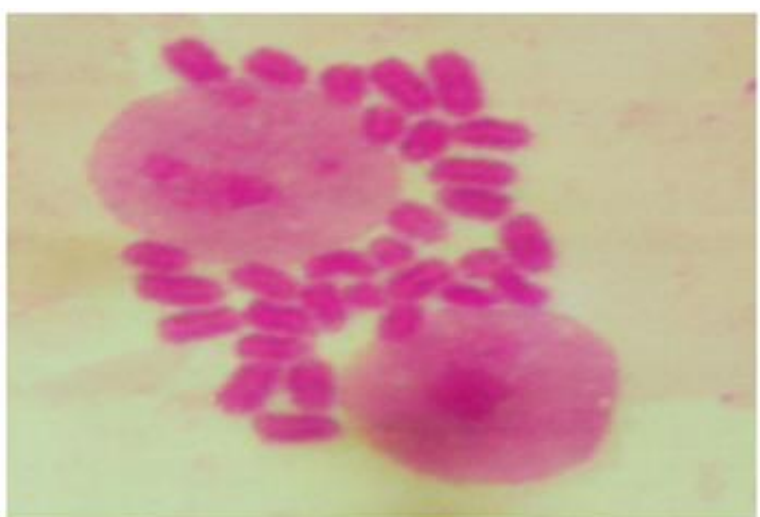

Figure (9): Photomicrograph ofmice primary spermatocytes showing Speamatogonial cell a fter treatment with varietv (9B-11) extract.

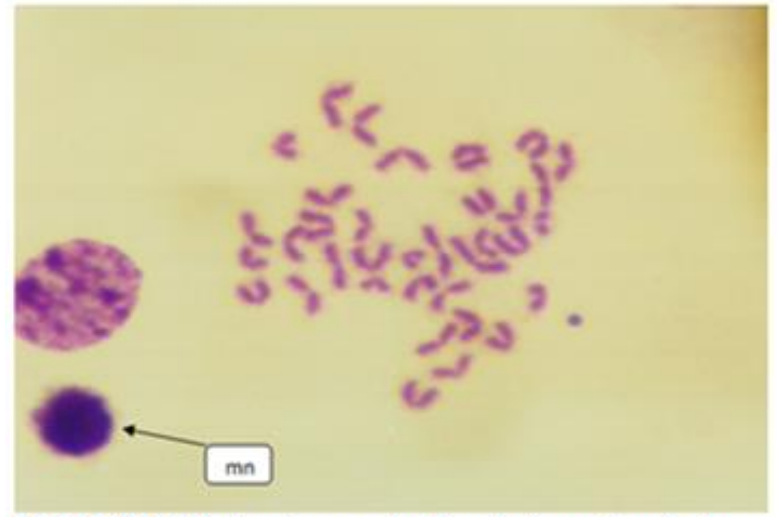

Figure (11): Photomicrograph of metaphases in mice bone marrow showing normal chromosomes and micronucleus (negative control).

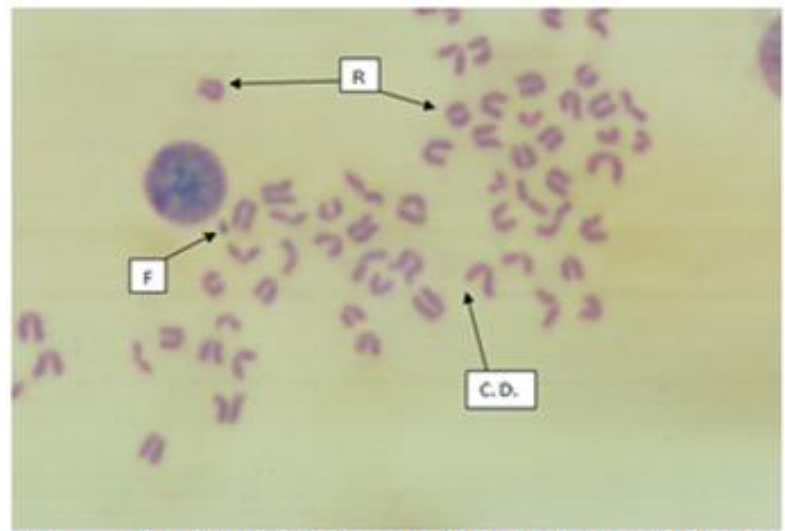

Figure (13): Photomicrograph of metaphases in mice bone marrow showing polyploidy, chromatid deletion (cd), fragment $(F)$ and ring chromosome $(R)$ after treatment with cyclophosphamide.

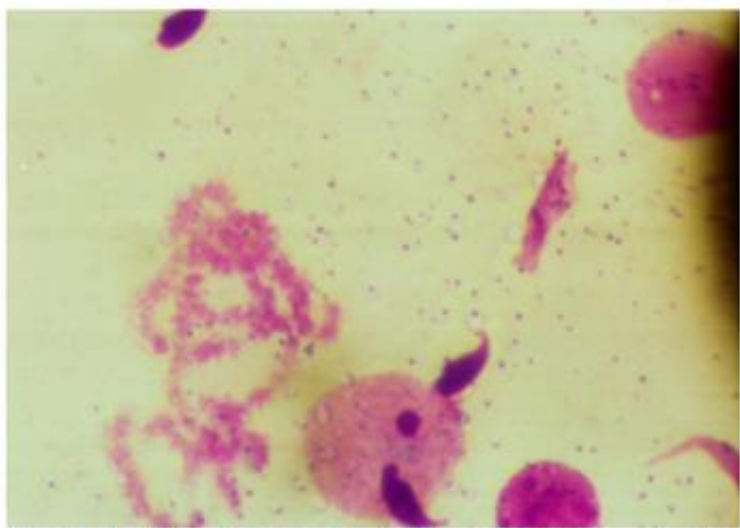

Figure (10): Photomicrograph ofmice primary spermatocytes showing sperm heads a fter treatment with variety (9B-11) extract.

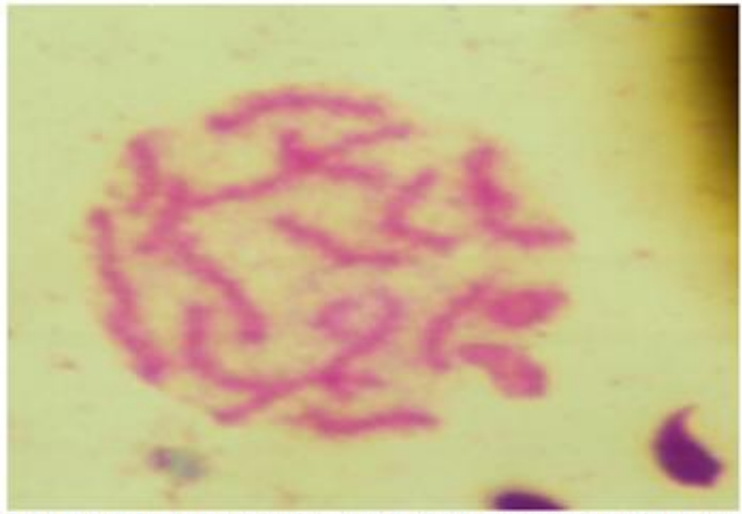

Figure (12): Photomicrograph showing nomal Diplotene stage of mice primary spematocytes and nomal sperm head (negative control).

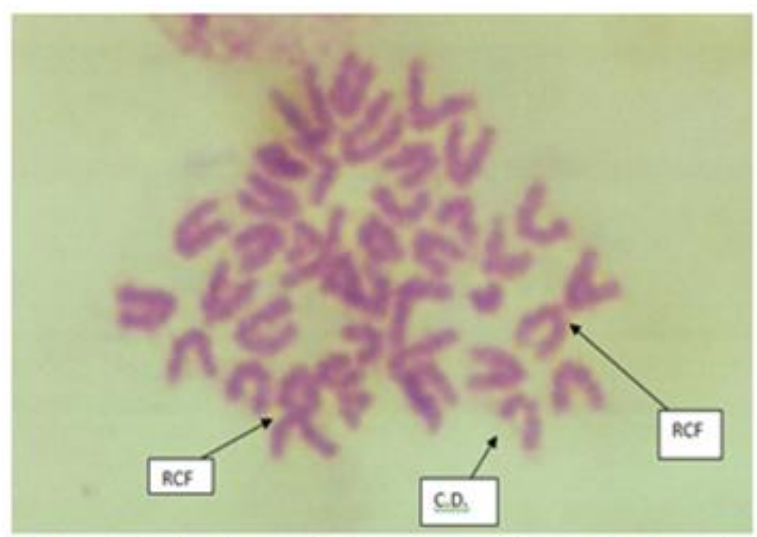

Figure (14): Photomicrograph of metaphases in mice bone marrow showing chromatid deletion (cd) and Robertsonian Centric Fusion (RCF) after treatment with cyclophosphamide. 


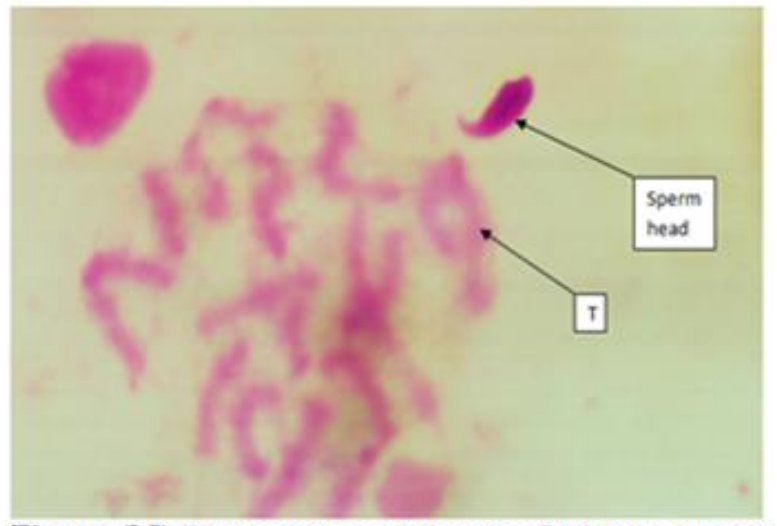

Figure (15): Photomicrograph showing Diplotene stage in mice primary spematocytes a fter treatment with cyclophosphamide. Note heterozygous reciprocal translocation( $(T)$.

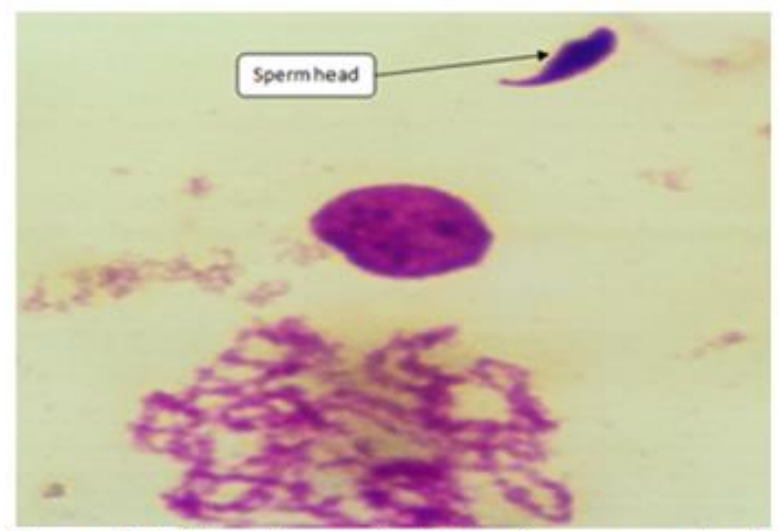

Figure (17): Photomicrograph ofmiceprimary spermatocytes showing sperm head and inversion after treatment with cyclophosphamide.

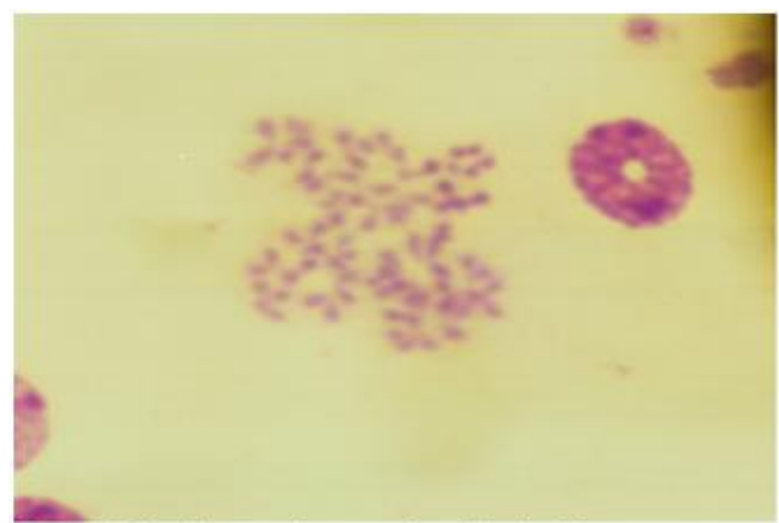

Figure (19): Photomicrograph of mice bone marrow showing chromosome degradation induced after treatment with Cyclophosphamide (positive control).

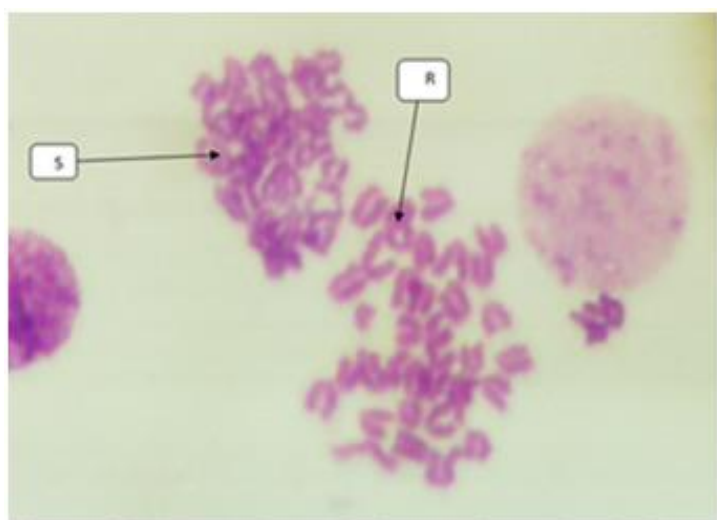

Figure (16): Photomicrograph of metaphases in mice bone marrow showing polyploidy with Ring chromosome (R) and high degree of stickiness (S) after treatment with cvcloohosohamide.

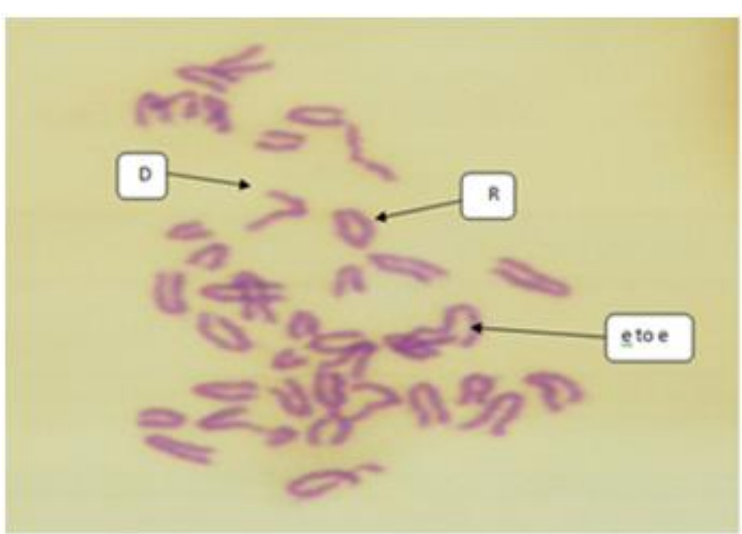

Figure (18): Photomicrograph of metaphases in mice bone marrow showing Ring chromosome (R), Chromatide deletion (D) and end to end association (e to e ) a fter treatment with cyclophosphamide.

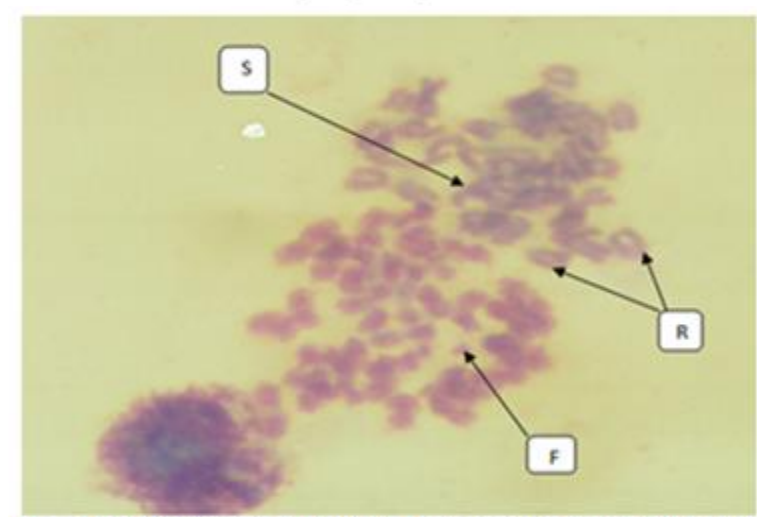

Figure (20): Photomicrograph of mice bone manow showing Polyploidy with Ring shromosome(R), Chromosome fragment and Stickiness induced after treatment with Cydophosphamide (positive control). 
J. Adv. Agric. Res. (Fac. Agric. Saba Basha)

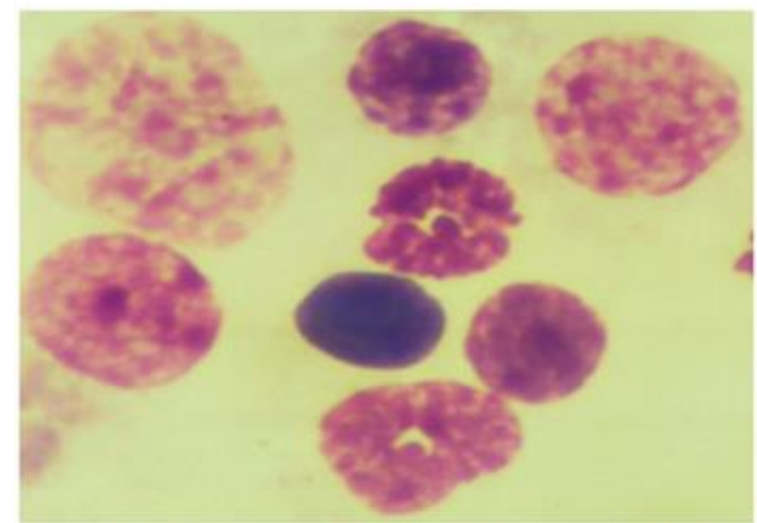

Figure (21): Photomicrograph of mice bone marrow showing binucleate induced a fter treatment with Cyclophosphamide (positive control).

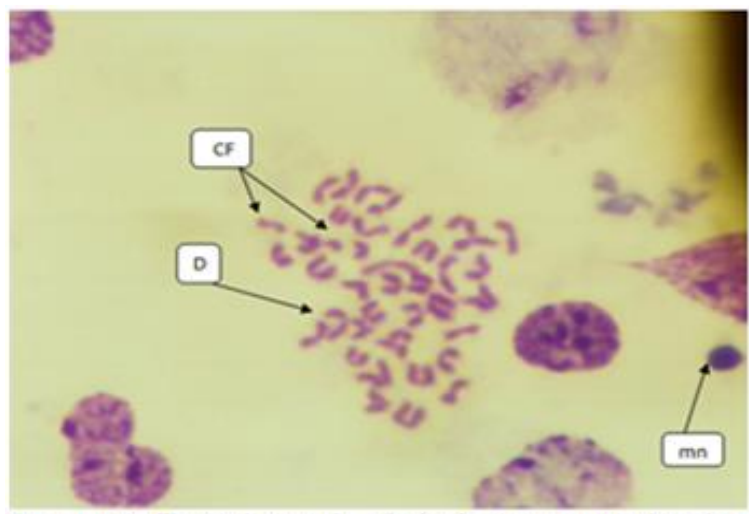

Figure (23): Photomicrograph of mice bone marrow showing Chromosome fragment, andchromatide deletion (D) induced after treatment with Cydophosphamide (positive control)

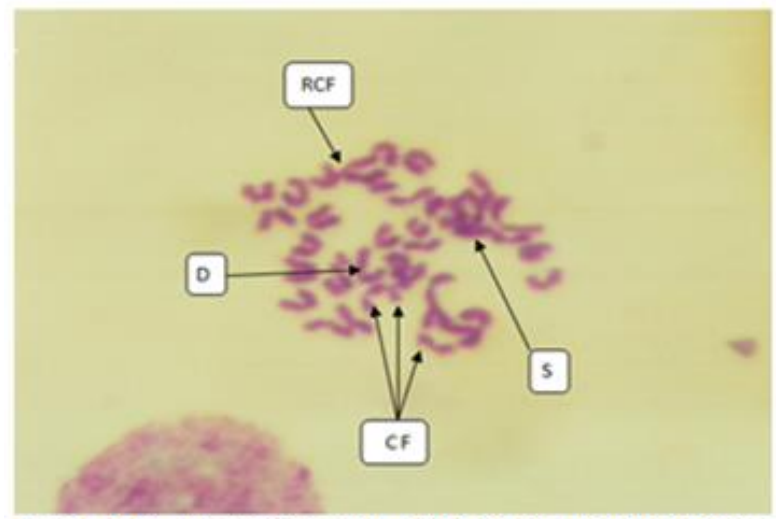

Figure (22): Photomicrograph of mice bone marrow showing Chromosome fragment (CF), Stickiness (S) Chromatide deletion (D) and Robertsonian Centic Fusion (RCF) induced after treatment with Cyclophosphamide (postive control)

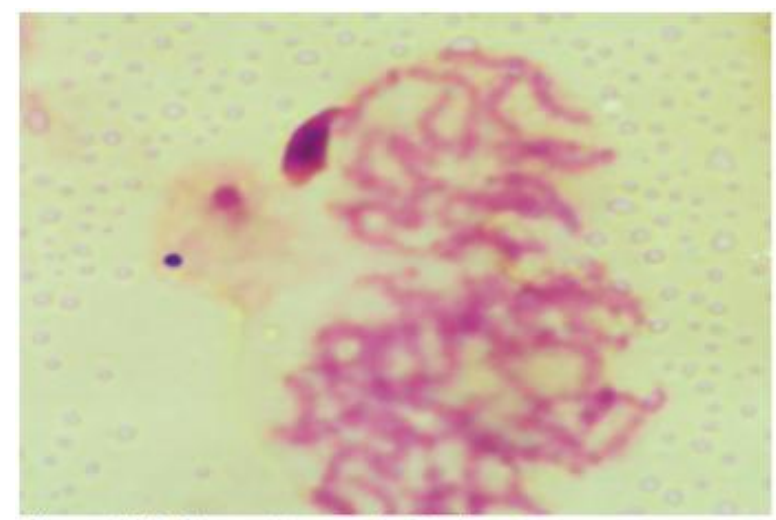

Figure (24): Photomicrograph of miceprimary spermatocytes showing Polyploidy and Inversion induced a fter treatment with Cydophosphamide (postive control).

Analysis of human lymphocyte cultures after treatment with the tested verities of Stevia extract proved that: 1 . No significant increase in aberration and 2. This extract is negative and was not capable in causing Primary DNA damage.

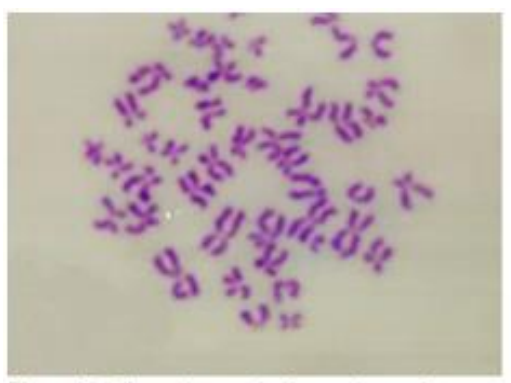

Figure (25): Photomicrograph of nomalmetaphase stage in humanlymphocytes after treatmert with Sponti variety extract.

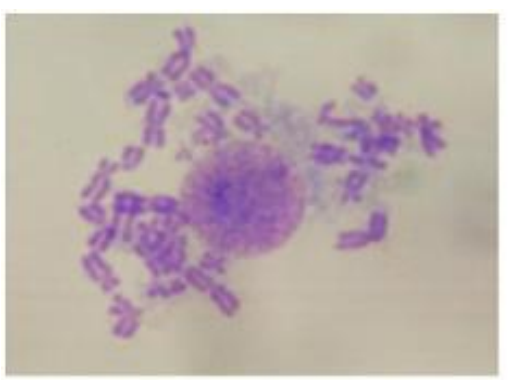

Figure (26): Photomicrograph of nomalmetaphase stage in humanlymphocytes a fter treatmert with variety (1108) extract.

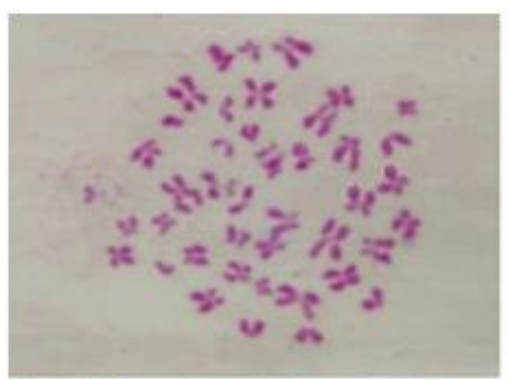

Figure (27): Photomicrograph of nomalmetaphase stage in human lymphocytes after treatment with variety (9B-11) extract.
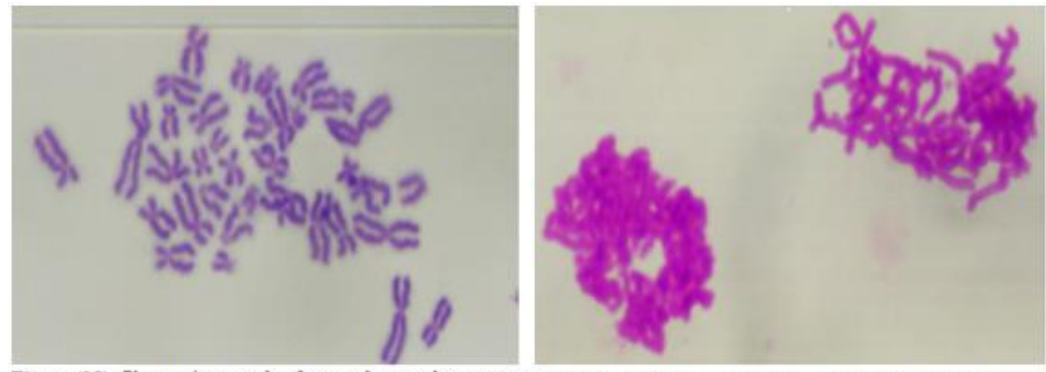

Figure (28): Photomicrograph of nomal metaphase stage Figure (29): Photomicogaph of metaphase stage in human in human lymphocytes (negative control). lymphocytes showing high degree of Stickiness induced by (EMS $0.02 \mathrm{M}$ ). positive control. 


\section{DISCUSSION}

The history of Stevia as a safe sweetener is very inconsistent. There has been controversial debate over its use from the date it entered the human foods. Also, the research that has been done to approve its safety for human consumption or confirm its deleterious effects has provided inconsistent results. For example, Stevia extract was evaluated for its genotoxic potential using the comet assay. This showed that Stevia extract and steviol do not have DNAdamaging activity in cultured cells and mouse organs (Sekihashi et. al., 2002). In contrast, in vitro Ames test was used to test the mutagenic effect of stevioside and steviol using Salmonella typhimurium TA 98 and TA 100 as the tester strains. Stevioside and steviol at the concentrations up to $50 \mathrm{mg}$ and 2 $\mathrm{mg}$ per plate respectively showed no mutagenic effect on both tester strains either in the presence or absence of metabolic activating system. However, at the high concentration both stevioside and steviol showed some toxic effects on both tester strains. While, the toxic effect was decreased in the presence of the metabolic activating system (Klongpanichpak et. al., 1997). Stevioside and steviol did not show any significant chromosomal effect in cultured human lymphocytes. This indicates that stevioside and steviol are neither mutagenic nor clastogenic in vitro at the used doses. However, in vivo genotoxic tests and long-term effects of stevioside and steviol are yet to be investigated (Suttajit et. al., 1993). Steviol was found to induce mutations at the guanine phosphoribosyltransferase gene (gpt) of Salmonella typhimurium TM677 wit metabolic activation. However, it is completely negative in the reverse mutation assays using E. coli WP2uvrA/pKM101 or S. typhimurium TA strains (Matsui et. al., 1996). Steviol was found to be mutagenic after metabolic activation in the forward mutation assay using Salmonella typhimurium TM677 (TM677). The results of obtained from such a research are in a harmony with those obtained by Würgler et al., (1986) on Drosophila; Matsui et al. (1989) on Salmonella typhimurium TA 100, TA98, TA102 and TA97 and Badawy et al. (2004) on Saccharomyces cerevisiae using different strains.

The present work revealed that Stevia as assessed by the short-term genotoxic bioassays carried out on Mice (Bone-marrow - micronucleus - and primary spermatocytes) was proven to be negative in inducing Macro DNA damage. On the other hand, it was found to be negative in causing primary DNA damage, such a result reflects the biosafty of Stevia usage for Human as a natural sweetener. These results are in agreement with those reported by Abdel-Tawab et al. (2004) who investigated the capability of stevioside to induce clastogenic effect in mice bone marrow. They found that no significant numerical or structural chromosomal aberrations observed in treated group or their offsprings. Roberts and Renwick (2008) examined the toxicokinetics and metabolism of rebaudioside A, stevioside, and steviol in rats for comparative purposes to determine whether toxicological studies conducted previously with stevioside would be applicable to the structurally-related glycoside, rebaudioside A. Overall, the data on toxicokinetics and metabolism indicated that rebaudioside $\mathrm{A}$ and stevioside are handled in an almost identical manner. These studies support the use of toxicological safety studies conducted with stevioside for the safety assessment of rebaudioside A (Roberts and Renwick, 2008). 
Genetic toxicology was simplified for the purposes of regulatory toxicology safety testing. Most agencies expect to see a limited test battery consisting of tests for gene mutation and chromosome aberrations. The International Conference on Harmonization $(\mathrm{ICH})$ core battery of tests is the best example of this approach, and this battery is expected to become the international standard for most testing requirements (Pugsley et al., 2008).

In conclusion, at the level of this study the use of Stevia rebaudiana (Bertoni) as a natural sweetener for human usage is recommended.

\section{ACKNOWLEDGEMENT}

The author is appreciated to Professor M. A. Seehy and Professor M. I. Massoud for thir critical reading of the manuscript.

\section{REFERENCES}

Abdel-Tawab F. M., Alia A. El-Seoudy, Nermin M., Abd El-Gawad, A.I. Allam and U.A. Foad (2004). In Vivo Evaluation of Biosafety of Stevioside. Proceed. Int. Conf. Genet. Eng. \& Appl., : 559-581.

Adler I.D. (1984). Cytogenetic Tests in Mammals, in: Mutagenicity Testing, A Practical Approach (Venitt, and Parry,J,M.,Eds.) IRL press, oxf.

Badawy, O.M., M. Z. Attallah and Elseehy (2004). Evaluation of Stevia Extract genotoxicity: I- Mitotic gene conversion and induction of monosomics in Yeast (Saccharomyces cerevisiae). . Int.Conf. Genet. Eng. \& Appl.

Bharat P., Y. Virendra, K. Amrita, S. Love and T. Binny (2013). Stevia (Meethipatti): Prospects As An Emerging Natural Sweetener. International Journal of Phamaceutical Sciences, Vol. 2(1): 214- 225.

Brusick, D. (1986). Principles of genetic toxicology.Plenum press; N. Y.

Brusick, D. (2003). Principles of Genetic Toxicology.Kluwer Academic Publishers Groups.

GAIN Report (2013/2014). USDA Foreign Agricultural Service, Global Agricultural Information Network, Egypt, Sugar Annual, Date: 5/23/2013.

Gollapudi, B. and O.P. Kamara (1979). Application of a simple Giemsastaining method in the micronucleus test.Mutat.Res., 64: 45 B 46.

Hart, J.W. and H. E. Pederson (1983). Statistics of the mouse bone marrow micronucleus test: counting, distribution and evaluation of results. Mutat.Res., 111: 195 - 207.

Ikan, R., V. Weinstein, Y. Milner, B. Bravdo and O. Shoseyov (1993). Natural glycosides as potential odorants and flavorants.ActaHorticulturae, 344: 17-28.

Jia, G.N. (1984). An experiment on the cultivation of Stevia rebaudiana.ShanxiAgricultural- Science-Shanxi-Nongye-Kexue. 1, 20-21. C.F. HorticulturalAbstract, 55: 06429.

Klongpanichpak, S., P.Temcharoen, C. Toskulkao, S. Apibal, and T. Glinsukon, (1997). Lack of mutagenicity of stevioside and steviol in Salmonella typhimurium TA 98 and TA 100.J.Med.Assoc.Thai. 80 Suppl 1: S121-S128.

Kolb N, J.L. Herrera, D.J. Ferreyra and R.F. Uliana (2001). Analysis of sweet diterpene glycosides from Stevia rebaudiana: improved HPLC method. J Agric Food Chem., 8: 105-111. 
Krejci, M.E. and D.A. Koechel (1992). Acute effects of carboxyatractyloside and stevioside, inhibitors of mitochondarial ADP/ATP translocation, on renal function and ultrastructure in pentobarbital-anesthetized dogs. Toxicology, 72: 299-313.

Matsui, M., K. Matsui, T. Nohmi, H. Mizusawa and M. Ishidate (1989). Mutagenicity of steviol: an analytical approach using the Southern blotting system. EiseiShikenjoHokoku, 83-87.

Matsui, M., K. Matsui, Y. Kawasaki, Y. Oda, T. Noguchi, Y. Kitagawa, M. Sawada, M. Hayashi, T. Nohmi, K. Yoshihira, M. Ishidate and T. Sofuni (1996). Evaluation of the genotoxicity of stevioside and steviol using six in vitro and one in vivo mutagenicity assays. Mutagenesis, 11: 573-579.

Medon, P.J., J.M. Pezzuto, J.M. Hovanec-Brown, N.P. Nanayakkara, D.D. Socjarto, S.K. Kamath and A.D. Kinghorn (1982). Safety assessment of some Sieviarebaudiana sweet principles. Federation Proceedings, 41: 1568.

Mondal S., Chhaya and De. Sirshendu (2012). Prediction of ultrafiltration performance during clarification of Stevia extract. J. Membrane Science, 396: 138-148.

Oud, J. L., J. H. de Jong and D. G. de Rooize (1979). A sequential analysis of meiosis in the male mouse using a restricted spermatocyte population obtained by ahy-droxy area /Triaziquone treatment. Chromosoma,71:237-248.

Pugsley, M.K., S. Authier and M.J. Curtis (2008). Principles of Safety Pharmacology.Br J Pharmacol., 154(7): 1382-1399.

Roberts, A. and A.G. Renwick (2008). Comparative toxicokinetics and metabolism of rebaudioside $A$, stevioside, and steviol in rats. Food and Chemical Toxicology, 46 S31-S39.

Schmid, W. (1975). The micronucleus test. Mutat. Res., 31: 9-15.

Seehy, M.A. (2007). Micro and Macro DNA damage induced be environmental contaminants .Ph.D. Thesis, Dept. Gent. Fac. Agric.Univ. of Alex.

Seehy, M.A. and M.A. Osman (1989). Evaluation of Nystatingenotoxicity: II Bone marrow chromosomes; micronucleus test; primary spermatocytes; and sister chromatid exchanges. Bull. Alex. Fac. Medicine, XXV(6): 16311636.

Sekihashi, K., H. Saitoh and Y. Sasaki (2002). Genotoxicity studies of Stevia extract and steviol by the comet assay. J.Toxicol.Sci., 27 Suppl 1: 1-8.

Shibata, H., S. Sonoke, H. Ochiai, H. Nishihashi and M. Yamada (1991). Glycosylation of Steviol and Steviolglucosides in extracts from Stevia rebaudiana. Plant Physiology, 123: 233-354.

Soejarto, D.D., A.D. Kinghorn and N.R. Farnsworth (1982). Potential sweetening agents of plant origin. III. Organoleptic evaluation of Stevia leaf herbarium samples for sweetness. 3. Nat. Prod. 5, 590-599.

Suttajit, M., U. Vinitketkaumnuen, U. Meevatee, and D. Buddhasukh(1993). Mutagenicity and human chromosomal effect of stevioside, a sweetener from Stevia rebaudiana (Bertoni).Environ.HealthPerspect, 101 Suppl 3: 53-56. 
Terai, T., H. Ren, G. Mori, Y. Yamaguchi and T. Hayashi (2002). Mutagenicity of steviol and its oxidative derivatives in Salmonella typhimurium TM677.Chemical and Pharmaceutical Bulletin, 50(7): 1007-1010.

Tomita T., N. Sato and T. Arai (1997). Bactericidal activity of a fermented hotwater extract from Stevia rebaudiana (Bertoni) towards enterohemorrhagic Escherichia coli $\mathrm{O} 157: \mathrm{H} 7$ and other food-borne pathogenic bacteria. Microbiollmmunol., 41(12):1005-9.

Toskulkao, C., L. Chaturat, P. Temcharoen and T. Glinsukon (1997). Acute toxicity of stevioside, a natural sweetener, and its metabolite, steviol, in several animal species.Drug. Chem. Toxicol., 20 (1-2): 31-44.

Würgler, F.E., C. Ramel, E. Moustacchi and A. Carere (1986). Assays for genetic activity in Drosophila melanogaster.In: Montesano, R.; H. Bartsch and $\mathrm{H}$. Vainio (Eds). Long-Term and Short-Term Assays for Carcinogens: A Critical Appraisal, IARC Sci. Pub. 83, International Agency for Research on Cancer, Lyon 395-407.

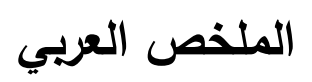

الامان الحيوى لمستخلص نبات الاستيفيا بتوظيف مجموعة من اختبارات السمية الوراثية

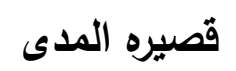

محمد عبد المنعم غنيمه

قسم التربيه والوراثه - معهل بحوث المحاصيل السكرية - مركز البحوث الزراعية

$$
\begin{aligned}
& \text { يههف هذا البحث الى تقييم الأثر الضار وراثياً لمستخلص نبات الاستيفيا. ولتحقيق هذا الهذف تم عمل } \\
& \text { اختبارات السمية الوراثية قصيرة الددى على الفئران والانسان كالتالى: } \\
& \text { 1- 2 - نحليل كروموسومات خلايا نخاع العظام فى الفئران. } \\
& \text { 2- تحليل الخلايا الاولية للحيوانات المنوية فى الفئران. } \\
& \text { 3- قياس الانوية الصغيره بخلايا الدم الحمراء غير الناضجة في الفئان النئران. } \\
& \text { 4- نحليل الثذوذ الكروموسومى فى مزارع الخلايا الليففاوية فى الانسان. }
\end{aligned}
$$

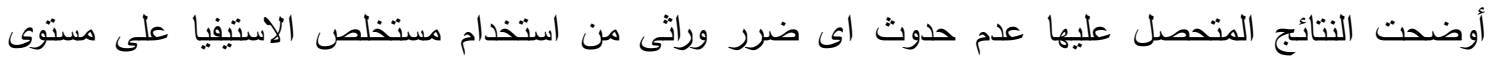

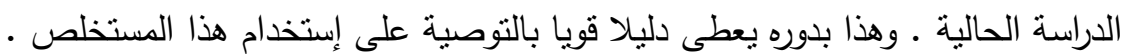

